\title{
COMMUNISMS AND COMMUNITIES: BRITAIN AND GERMANY BETWEEN THE WARS
}

Arbeiterbewegung und Selbstverwaltung. By Volker Wünderich. Wuppertal: Peter Hammer Verlag, 1980. Pp. 290. DM 36.00.

Little Moscows. By Stuart Macintyre. London: Croom Helm, I980. Pp. 2 I 3. f 11.95.

History of the Communist Party of Great Britain. By James Klugmann. 2nd edn. London: Lawrence \& Wishart, 1980. 2 vols. Pp. $38 \mathrm{I}+373 . £ 7.90$.

Arbeiterpolitik im Betrieb. By Uta Stolle. Frankfurt, New York: Campus Verlag, I980. Pp. 336. DM 39.0o.

Der Verhältnis der KPD zu den Gewerkschaften in der Weimarer Republik. By Freya Eisner. (Schriften der Otto Brennert Stiftung 8.) Köln, Frankfurt: Campus Verlag, I977. Pp. 27r. DM 28.00.

Arbeitslosigkeit und Rationalisierung. By Eva Cornelia Schöck. Frankfurt, New York: Campus Verlag, 1977. Pp. 280. DM 24.00.

National-Bolchevisme. Stratégie communiste et dynamique conservatrice. By Louis Dupeux. Paris: Librairie Honoré Champion, 1979. 2 vols. Pp. vii +743.

Die Partei kämpft wie ein Mann. By Silvia Kontos. Basel, Frankfurt: Stroemfeld/Roter Stern Verlag, 1979. Pp. 283. DM 25.00.

Der Freiheit eine Gasse. Geschichte der Düsseldorfer Arbeiterbewegung. By Wilhelm Matull. Bonn: Verlag Neue Gesellschaft, I980. Pp. I87. DM 16.oo.

Kommunalpolitik der KPD im Ruhrgebiet 1924-1933. By Beatrix Herlemann. Wuppertal: Peter Hammer Verlag, 1977. Pp. 339. DM 26.oo.

Let us begin by quoting two recent works on the history of European Communism - a question:

Why was it that parties which were manifestly and profoundly undemocratic in their internal organization, and which remained associated with the Soviet Union over a long period when it was the object of a constant barrage of very effective bourgeois propaganda, much of it based on historical facts, nevertheless won and kept the freely consented allegiance of the vanguard sectors of their national working class?

and part of an answer:

The social consequences of the financial situation of the municipalities were very serious... Cuts in wages and salaries hit all those in municipal service; dismissals were particularly common in the education service. Cultural activities, housing construction and road building were completely halted... All welfare payments not directly related to unemployment were reduced by more than one third... That the administration's economic measures were pushing the population to the limits of its endurance was indicated by the reason [offered in an official request for] aid to the municipalities: 'Disturbances in the larger industrial towns' could 'all too easily become a signal for general uprisings of the hungry and desperate unemployed'. 
The juxtaposition of these two passages suggests a series of paradoxes. The question that appears at the centre of Perry Anderson's discussion of Communist party history in the History Workshop anthology People's history and socialist theory, ${ }^{1}$ while it addresses a general European phenomenon, is unmistakably a product of the peculiar experience of English Communism. This is a movement characterized by a self-confidence, rooted equally in academic and proletarian subcultures, stretching back over more than sixty years. Its organizational continuity was hardly shaken before the cataclysm of 1956 -hence the long perspective implied in Anderson's question and its particular emphasis on the problems of the credibility of the Soviet Union as model and guide. And the complement of this continuity has been isolation from mass electoral politics at the national level (at its largest, in I 942-3, the CPGB was about one-sixth the size the German Communist party had been in 1932) - a circumstance which adds apologetic force to expressions like 'vanguard sectors'.

The second passage comes from Volker Wünderich's recent study of Communism and local government in Weimar Germany. The problems posed by German Communism are not those of a narrowly based but enduring tradition. For the German Communist party (KPD) suffered a fatal break in continuity, suppression of the movement by the National Socialist regime followed with heartbreaking rapidity by the execution or disappearance of many of its leading personalities in Russian exile. And if, as the conventional historical wisdom holds, the circumstances of its suppression were to some extent of the party's own making, then it has to be said that that break in continuity was the price of the KPD's success in the popular political arena. The growth of the KPD to mass membership and electoral support in the depression (though it could never claim to represent more than a sizeable minority of the working class) was a manifestation of the fact that the German labour movement was deeply split, and this at the very time when the rise of Nazism presented it with its greatest historical challenge. So the question that presents itself to historians of Germany is Anderson's turned inside-out: Why should Communism in Germany have appealed beyond a 'vanguard ' to a large popular constituency, and why did it nevertheless fail even to ensure its own survival? In Wünderich's answer, Moscow hardly figures at all. This is representative of a new trend in KPD historiography, for the KPD's links with the Comintern leadership were perhaps the closest of all Communist parties' and were certainly the most highly valued by the Soviets, and the influence of Moscow, as transmitted through one of the most 'manifestly and profoundly undemocratic' of Communist party organizations, has long been held to blame for the KPD leadership's pursuit of a policy calculated to exacerbate the divisions within the labour movement. Though Wünderich is by no means the first to have made this departure, his is the first published study to deal both sympathetically and critically with the role of the Communists in that political arena furthest from the concerns of Moscow, namely local government.

There is one final paradox in the fact that this readjustment of focus in the study of German radical politics reveals a configuration of political and social crisis not startlingly different in detail from the one that faces the British left today. With important differences, Germany in the years before Hitler's 'seizure of power' and Britain in the 1980 s both provide examples of how the strains placed on the material and ideological resources of the welfare state by economic contraction have led to

1 (London, 198I), pp. I 5 If. 
conflicts played out at first, and with great ferocity, within the framework of local politics and then in relations between central and local government. In Germany, of course, the question of preserving the welfare state became a central issue in national politics; the resignation of the cabinet of the Social Democrat Müler after its failure to find a politically acceptable means of meeting the state's financial obligations to the growing numbers of unemployed is usually regarded as the beginning of the end of Weimar democracy. But as Wünderich makes clear, the erosion of democratic principles, in the form of challenges to local autonomy which were directly related to conflicts over the provision of welfare and other services, set in earlier and went deeper than the study of cabinet politics reveals. In an unmistakable echo of 1930 Marxist analyses of German fascism, he writes of a 'process of fascization' from the late 1920 onward, and argues from the premise that the mounting of a counter-offensive to this process was the central problem for the KPD and the labour movement as a whole. At this level of analysis, the problems of labour's strategy in Weimar Germany appear to be at least analogous to those now addressed in this country by a growing body of theoretical and historical work on the relationships between the 'local state', social policy and working-class political action. ${ }^{2}$

This must be one reason why English and German approaches to the history of Communism have converged on the study of local communities, as the publication in the same year of Wünderich's Arbeiterbewegung und Selbstverwaltung and Stuart Macintyre's Little Moscows suggests. There are other grounds for this convergence, which involves the simultaneous rediscovery of the locality as a unit of political organization and the role of shared social and political interests outside the workplace in the activity of Communist parties. But while British and German scholars ought to have a good deal to say to one another, their works differ sharply in style and form; they bear the distinguishing features of their respective political and academic traditions.

Much in the British experience, including the character of British Communism as a living tradition and the left's history of self-conscious involvement in local government, has made it more or less inevitable that historians would come to concentrate on the ways Communist militancy addressed and became rooted in the problems of daily life of the working class before the Second World War. Even James Klugmann's recently reissued official history of the CPGB, although it has been properly criticized for an apologetic concern with leadership policies that extends to the point of suppressing entirely the role of the Comintern, gives more detailed attention to the role of the party in unemployed struggles at the local level than any general account of the KPD, official or otherwise, published since the war.

In Germany the search for a framework for understanding the social basis of Communist success has been carried on as a process of elimination marked by both conscientious scholarship and vigorous polemics. After several years devoted to the critical analysis of Comintern theories of fascism, ${ }^{3}$ younger scholars have during the

2 Cynthia Cockburn, The local state (London, 1977); John Cowley et al., Community or class struggle? (London, 1977); Jennifer Dale, 'Class struggle, social policy and state structure', in Joseph Melling (ed.), Housing, social policy and the state (London, 1980).

3 The most influential works of Ideologiekritik include Alexander von Plato, Zur Einschätzung der Klassenkämфfe in der Weimarer Republik (Berlin, 1973); Oskar Negt and Alexander Kluge, Offentlichkeit und Erfahrung (Frankfurt, 1972); Nicos Poulantzas, Fascism and dictatorship (London, 1974). 
past five years or so turned to scrutinizing various aspects of and approaches to the constituency of the KPD. This has been the logical consequence of the reaction against the view taken by the 'classics' of KPD historiography up to the late 1960 , in which the KPD was seen as mechanically carrying out a Moscow-dictated policy so absurd that individual Communists must either have been perfectly disciplined automata or have beaten a hasty retreat whenever asked to put the policy into effect." But the effort of looking away from Moscow to the peculiarities of German society and politics that informed the direction of German Communism has only confirmed some historians' impression that the peculiar intellectual posture of the KPD leadership prevented it from effectively handling the constituency it attracted. In recent works on the $\mathrm{KPD}$, Moscow is beginning to find its way back in through the rear door; the Comintern now appears most frequently not as Stalin's henchman, but as the arbiter of theoretical correctitude to a German movement whose leaders took Marxist theory very seriously. This is important, since some analysis not only of the internal logic of Comintern theory but also of its practical consequences and its credibility in the light of people's experience must form part of the reintegration of the social, institutional and ideological approaches to KPD history.

Such is the view of the role and significance of the Comintern taken by Uta Stolle in her pioneering set of case-studies, Arbeiterpolitik im Betrieb. It is worth noting, though, that in her case the discussion of KPD policy in its global aspects remains confined to a short analytical excursus. Her studies of relations within the workforce of four industrial enterprises were initially intended to underpin an examination of the shopfloor origins of the theory of 'social fascism' that provided the rationale for the KPD's assault on the Social Democratic leadership of the labour movement after 1928. But they have grown to fill a volume of their own, edging out explicit discussion of the larger question, and Stolle's theses on the genesis and function of the theory, though more than sensible, bear little direct relation to the case-studies. This does not diminish the book's value as a contribution to our understanding of why and how the German labour movement was divided by the beginning of the rg3os. Indeed, one happy consequence of the author's choice of four different kinds of cases - chemical workers at the Bayer and BASF plants, workers for the electrical components manufacturer Bosch, and skilled workers in the Solingen metalworking trades - is that she is able to offer counter-examples to many one-sided hypotheses about where and why the lines between Communist and 'Reformist' (or Communist and oppositional Communist) were drawn. Her approach is a conjunctural one, primarily concerned at each stage with the capacity of workers to organize to enforce their collective interests. She traces a general diminution of that capacity to the consequences of industrial rationalization in the 1920 , but also demonstrates how in particular cases the subjective assessment of the prospects of success (or the experience of failure) combined with the presence or absence of an institutionally sustained radical tradition to encourage or inhibit support for Communist and other oppositional movements. In the chemical industry, for example, an unskilled workforce confronted conditions of work and employer attitudes that frustrated shopfloor communication and collective organization. The weakness of the chemical workers' organizational tradition meant that crises could generate considerable support for the Communist trade union organization as the most radical voice in

- The 'classics' include Ossip K. Flechtheim, Die KPD in der Weimarer Republik (2nd edn, Frankfurt, 1969); Hermann Weber, Die Wandlung des deutschen Kommunismus (2 vols. Frankfurt, 1969); Siegfried Bahne, Die KPD und das Ende von Weimar (Frankfurt/New York, 1976). 
the factory, but that that support could just as easily dissolve when the thin stratum of Communist militants was removed from the factory or when a Communist-led action appeared in the short term to have failed. Bosch, on the other hand, provides an example of a self-conscious radicalism built on the historically strong position of skilled workers in the labour market. Here the strength of the Communists in the trade union throughout the 1920 s was a function of the strength of trade unionism itself. When, after 1928 , the official KPD adopted its policy of splitting the trade unions, the majority of union activists at Bosch went into the Communist opposition (KPO) rather than accept what they saw as an entirely self-defeating policy. The determining factor for those who remained with the KPD, as far as Stolle can see, was their personal tie to the party, expressed as a high degree of party discipline - an extreme version of the same loyalty to institutionalized traditions that made their fellow militants plump for trade-union unity.

In capturing in detail the contradictory interactions between party practice and industrial circumstances, Stolle's work represents an advance on previous works on the KPD and the trade unions, where the tendency has been to reiterate - from varying perspectives and in different theoretical idioms - a long-since recognized truth: Within the official institutions of the German labour movement as a whole, Communism remained relatively weak. With important regional and sectoral exceptions, the Communists proved unable to win decisive influence in the trade unions from the 'Reformist' leadership, whether KPD policy was one of working within 'trade-union legality' (as it was between 1920 and 1928), or one of openly challenging the bureaucracy through the formation of independent organizations (post-1928). Freya Eisner's conscientious study of the official sources, very much in the classic tradition of KPD history from the Comintern down, provides a valuable outline of the development of policy, including a helpful account of the pre-war background to party-trade union relations. Eisner offers no surprises, and her analysis is coloured by a liberal humanism which, though wholly admirable in itself, makes the internal critique of revolutionary strategies very difficult. The full extent of her assessment of the KPD's social programme is that it proposed 'little that was practicable' (under any political circumstances), and when she follows this statement with the question 'whether despotic action [namely, the violent overthrow of the state] is not by its very nature bound to preclude socialization', the reader is bound to wonder why she chose to study the Communist movement at all. Eva Cornelia Schöck has taken a more sympathetic view of the KPD's aims, while attempting to uncover the structural limitations to its success. Like Stolle, she starts from the premise that the sources of division within the labour movement that gave 'social fascism' a certain credibility must be sought in the conditions of work of the German working class. Like Stolle, she sees the industrial rationalization on which the stablization of the German economy rested in the mid-rg2os as a crucial moment in the shifting balance of power between labour and capital and between different sections of the working class. But although she too examines different groups of workers in turn - miners, chemical workers, metalworkers - her approach is a more generalizing one. She fixes on the consequences that concentration and rationalization had for broad patterns of employment, and concludes that for significant sections of the workforce rationalization meant first a radical insecurity - "The German workforce was swept into the process of production and cast out again in a way that was new in the history of capitalism' - and finally chronic joblessness (a problem that did not escape contemporary observers). She interprets the 
development of the Communist trade union organization (RGO) in the light of an increasingly significant division between employed and unemployed which became critical during the depression years after 1928 . The RGO is described as a 'helpless reflex of capitalist development', in that it addressed and attracted precisely those groups most affected by the rationalization process: unskilled, unorganized and young workers, women and especially the unemployed. Although its aim in doing so was to bridge the gaps between various sections of the working class, the effect of RGO activity was to institutionalize the divisions. While propagating a line ('social fascism') which, as Stolle too demonstrates, had the fewest resonances within the trade union context before r930, the Communists managed to summon to their banner those sections of the working class least able to carry on a sustained and effective revolutionary fight.

In her conclusions, Schöck does not distinguish systematically between political and economic divisions within the labour movement, but the tendency of her argument is to present the political division as a simple reflex of large-scale economic change, and she has been justly criticized for this. ${ }^{5}$ She has nevertheless added a new dimension to the assessment of the KPD and its constituency. The image of the KPD as a party of the unemployed is itself a familiar one; a Comintern spokesman estimated in 1932 that eighty per cent of KPD members were out of work (probably an exaggeration), and even in periods of relative prosperity the KPD membership included disproportionate numbers of unemployed. The weakness of the KPD presence among workers in work was compounded by the preference that even employed KPD members showed for carrying on their political activities outside the workplace; in spite of constant urgings from the leadership, the movement for the creation of factory cells was a dismal failure. The perception of this has long been treated as sufficient grounds for disqualifying the KPD as a party of the working class, not least by students working within the KPD's own ideological tradition, for whom the discounting of the unemployed as a revolutionary force rests on the compelling proposition that the working class learns both to perceive and to exercise its collective power at the point of production. Schöck's has been the first major work to make clear that we cannot disqualify the KPD without disqualifying the actual experience of the working class in the I920s.

The next step for historians has been to examine the positive aspects of the KPD's activities outside the workplace. If the Communists were largely absent from the place of work and the work-based institutions of the labour movement, where were they present? What positive aspects of the lives of non-workers (or the non-working lives of workers) did they address, and why were they successful when and where they were? Perhaps the least convincing attempt to redefine the KPD in terms of the social groups it appealed to has come from the French scholar Louis Dupeux. His book is largely devoted to the examination of that peculiar phenomenon of the Weimar Republic, national bolshevism. He argues cogently against the idea of an actual convergence of left- and right-wing radicalisms in the r 920 , but gives special attention to the nationalist elements in Communist theory and agitation. These emerged at those moments when the KPD was actively engaged in openly revolutionary agitation and at the same time facing a challenge from radical

5 See James Wickham's article 'Social fascism and the division of the working-class movement', Capital and Class, vil (1979), 1-65-which represents an original and very convincing attempt to integrate economic and institutional accounts of the division between Social Democrats and Communists. 
nationalist or fascist popular movements; at times, that is, when it was at its most outspokenly radical and also at its most successful in recruiting members and voters, namely r 923-4 and 1929-33. In each of these periods, nationalism was allied in KPD rhetoric with an appeal to the common struggle against capitalism of all 'labouring people' (Arbeitende or Werktätige), terms which were explicitly intended to embrace the various sections of the petty bourgeoisie and the agrarian population as well as industrial workers. It is this appeal to the middle classes that fascinates Dupeux. His argument that it began as a tactic for dividing the 'fascist' camp but became part of a necessary strategy for 'finding at last a majority basis for the proletarian revolution' is persuasive, though he acknowledges that the KPD never abandoned its conviction that the true revolutionary majority was the majority of the working class. But Dupeux overestimates the clarity and consistency of Communist thinking on the revolutionary potential of the professional and clerical middle classes, and his attempt to re-situate KPD policy historically in the light of its novel appeal to the bougeoisie verges on the surreal. His interesting conclusion that the appeal to the nationalist middle classes contained 'more Lassalle than Marx' is partially bolstered by the fact that the earliest groups of nationalist Communists of the $1920 \mathrm{~s}$ openly acknowledged their ideological debt to Lassalle. But those groups were excluded from the movement early on. The terms in which the alliance of proletariat and middle classes was invariably presented within the ambit of the Comintern, namely the establishment of the 'hegemony' of the former over the latter, bespeak most clearly the more immediate influence of Lenin. Still more difficult to accept is Dupeux's assertion that the nationalistic, populist programmes of the 1920s should be seen as the bridge between the Lassallean tradition and the popular front, the compromisso storico and Eurocommunism. Here he offers no justification for revising the conventional view that the compromises of international Communism since 1935 have represented tactical alliances with bourgeois leaderships whose precondition was the abandonment of the kind of 'ultra-leftist' positions that encouraged those early appeals to sections of the lower-middle-class 'rank and file'. The two strategies are equally manifestations of Communism's casting about for new sources of strength and legitimacy after the epochal disappointment of its revolutionary expectations. But they had very different implications, both for national politics and, not least, for the character of Communist party activity 'on the ground' and the attitudes of its own rank and file. This might have been more apparent to Dupeux if he had given more attention than he does to the social context and effects of the respective appeals to the middle classes.

In fact (and Dupeux does not deny this), the KPD never had much success among the 'labouring masses' of the petty bourgeoisie, although there is still room for serious study of the very vigorous efforts it made to organize in the countryside. From the point of view of the party's actual constituency, the appeal to the middle classes should be seen as an emblem, to some extent a legitimating device, for a very much more general shift of agitational attention away from the factories and the organized workers inside them during putatively revolutionary periods. The efforts of the KPD to organize around aspects of working-class life outside the workplace, including unemployment and welfare provision, rents and evictions, women's rights and abortion, juvenile justice and police and fascist violence, I have elsewhere referred to as 'street politics'. (It may be worth noting that the term, though not current

- See my forthcoming book, Beating the fascists? The German Communists and political violence 1929-33 (Cambridge University Press). 
in the German context, was used by London Communists to describe analogous activities in the 1930s, practices which were abandoned and proscribed by the CPGB in the wake of the popular front.) ${ }^{7}$ As historians have begun to examine these aspects of KPD activity, and the way the party attracted certain social groups by making appeals to their specific, immediate, collective interests, it has become clear that the KPD was considerably more open, original and wide ranging in its agitational concerns than conventional accounts have allowed for. It has also become possible to reassess the party's self-image and to consider the implications of the gap between what the party said it was doing (and thought it ought to be doing) and what it was doing. Very often the prescriptive workerism of the party resulted in the rapid alienation of those who had been won through its 'street politics'. This is perhaps most obvious in the case of the party's organization of women, where the KPD was very active but gained little in terms of female membership or electoral support. Silvia Kontos has examined this aspect from the point of view of today's feminist movement, in a book with the telling title (taken from a speech by one of the Comintern leaders) Die Partei kämpft wie ein Mann. She regards as a fundamental weakness the party's received understanding of the ends and means of politics and its failure to break through to a redefinition of the relationship between the personal and the political (such as Wilhelm Reich was already pleading for), which meant that its engagement with women's issues stopped short at the mechanical functions of 'reaching out' and 'mobilizing' them as one of a series of 'allied strata'. But she concludes nevertheless that 'the KPD...to some extent against its own official intentions, represented an emancipatory milieu for women'. ${ }^{8}$ The same sort of contradictory image has emerged in recent studies of the KPD's work among the unemployed, which was one of the mainstays of the Communist organization throughout the r 920 s. $^{\circ}$

In both these cases, though, emphasis is put on contradictions that operate in the realm of psychology or ideology, as differences between the needs or intentions of the party and those of its recruits. The unit of study is still the broad social group (defined by economic circumstance or by gender) whose members were individually attracted by KPD agitation. But it should be possible to reintegrate the disparate elements of the population outside the factories that the KPD appealed to, and thus to reach some kind of general characterization of German Communism in terms of their relation to the institutions and arenas of social conflict peculiar to the I $9^{20}$. The practical problem for the KPD then becomes a wider one than its relative readiness to acknowledge the felt wants and emotional needs of its recruits, namely its capacity to recognize and respond to the conditions of political activity specific to the terrain on which it had recruited them.

Marxist theory calls the struggles of women, the unemployed and others addressed by the KPD's 'street politics' struggles in the sphere of reproduction. Had the Comintern chosen to employ that analytical device it might have been able to add an element of conviction to its mechanical assertions that any and every fight undertaken by the Communists was a fight against capital. But the 'sphere of reproduction' is not a notably effective rallying cry. Without some sense of the

7 Joe Jacobs, Out of the ghetto (London, 1978 ), Pp. ${ }_{5}{ }_{1} \mathrm{ff}$.

8 Cf. the conclusions of Atina Grossmann, "Abortion and economic crisis: the 1931 campaign against $\$ 218$ in Germany', New German Critique, xIv (1978), 1 19-37.

- Rosemarie Huber-Koller, 'Die kommunistische Erwebslosenbewegung in der Endphase der Weimarer Republik', Gesellschaft. Beiträge zur Marxschen Theorie, 10 (1977), 89-140. 
specific institutional manifestations of that struggle, neither the Communists nor those who study them could begin to grasp either why the KPD won recruits when it organized in that sphere or how successful it could expect to be there. Here I think the concept of the welfare state is crucial. The social groups which had in common their separation from the process of production also shared, as a central element of their experience of social relations, an ambivalent relationship to various agencies of the state, often a relationship of financial dependence. These agencies and the services they dispensed were as much products of the revolution of 1918 as was the KPD, having been centralized, consolidated or (in the case of state unemployment insurance) created since the First World War. The way in which the Weimar Republic combined the beginnings of a welfare state with the legacy of the Imperial police state, against the background of a severe contraction in the job market, gave a new edge to the question of popular influence on and control of public agencies. Of the working-class parties, the KPD was the only one equipped by its revolutionary programme to play the role of adversary to the state at every level of politics; Social Democracy was the pillar of the Weimar system, its representatives in important regions like Prussia most visible to the working class as administrators and dispensers of state services (or, as they all too often appeared, withholders of services and dispensers of police justice). The point is frequently made that the propaganda of 'social fascism' had its most powerful resonance in this sphere. (It appears also to be true that the Communist trade unions had some attraction for municipal workers.) The problem that the KPD faced in this context arose partly from its inability to see these conflicts as constituting a particular kind of struggle with its own immediate aims and limitations. The Communist preoccupation with class struggle at the point of production, manifested in the Comintern's social psychology as economism and workerism, meant that the KPD persisted in trying to legitimate its 'street politics' by drawing mechanical analogies with industrial struggles. The labour exchange, the school, the borstal, the apartment block were each hypostatized in turn as the moral and strategic equivalent of the factory. Given the place that the factory holds in Marxist analyses as the location at once of the collective grievance, collective identity and collective strength, the drawing of such analogies could only serve to reinforce an illusion of success. It obscured the fact that the experience of the working class in its relations with state institutions, though it may generate a sense of common grievance, is often in itself a demonstration of weakness, and that the preconditions for success in confrontations with the state (armed as it is with the powers and means of physical coercion) are different from those operating in industrial conflicts. The tendency of the KPD leadership obstinately to claim victories at the very times when it was leading its supporters into defeat after defeat is easily attributed to propagandistic mendacity or sheer bloody-mindedness. If we can see it as the logical consequence of a gap in Comintern theory, which made it unable to accommodate important changes in the situation of the working class, perhaps we can befin to assess its implications for the relationship between the leadership and the party's constituency, and for KPD practice as a whole, more clearly.

In order to pursue this kind of analysis we need more studies of the operation of the KPD in the localities, not only at the level of 'street politics' but also at that of administrative politics, where control of state agencies is openly contested. Germany, like Britain, had its 'Little Moscows', towns and districts where Communists regularly won at the polls and were able to make a significant impact 
on local politics, though there were differences between the British and German experiences, to which I will return. The extent to which memories of that tradition have been allowed to die is illustrated by Wilhelm Matull's slim volume. It purports to be a history of the labour movement in Düsseldorf, but is probably best described as a Festschrift for the local SPD. For Matull gives the KPD only minimal attention, in spite of the fact that it consistently outpolled the SPD in the town (the socialist labour movement as a whole being seriously challenged at all times by the Catholic Centre party and Christian trade unions). Of two recently published memoirs of the resistance to National Socialism, he remarks that the details 'need not be repeated here, particularly since they consist of information relating largely to the KPD'. The motives of a very respectable socialist publishing house in issuing this kind of work at this late stage in discussions of German labour history are obscure.

The strength of the Communist movement throughout the Rhine-Ruhr industrial area has meant that that area has produced the most important studies of the KPD in local government. Beatrix Herlemann has taken a fairly conventional approach to the activities of KPD representatives in the local governments of the Ruhr district between 1924 and 1933 . She describes in some detail the positions adopted by the KPD delegations on local councils at various points and on various issues, against the background of an exposition of the official KPD attitude to local politics and conflicts within the local parties. She is able to illuminate, as a central problem in KPD politics, the tension between the need to effect improvements in the immediate situation of the local working class through practical work and the interests of agitation and mobilization, which often dictated that Communists remained aloof from co-operation in the day-to-day running of government and used representative bodies as platforms for the assertion of their distinct revolutionary identity. But her conviction that the former was both desirable and possible within the structures of the democratic Republic, indeed that it represents in itself the appropriate aim of left-wing politics, deprives the book of any theoretical dynamic. A characteristic chapter heading is 'The phase of relatively realistic [sachliche] co-operation', and it is only in this phase ( $\left.1925^{-8}\right)$ that Herlemann sees the KPD as an effective force in politics - at that period when the movement had made the tactical decision to downplay its revolutionary character; when the KPD, so to speak, was least itself.

Volker Wünderich's theme is essentially the same tension, but he approaches it from premises and in terms that offer openings for wider political and historical discussion. Where Herlemann posits the possibility of reform based on participation in the political process, Wünderich sees the necessity for organizing to win immediate partial concessions ( Teilforderungen), not because these could constitute the beginnings of peaceful transformation of social relations but because the situation was one in which they represented the only alternative to counter-revolution, and consequently the only guarantee for survival of the revolutionary impulse. Put in these terms, of course, the dilemma of the KPD emerges from the shadows of political pathology and appears as one of the most familiar objects of socialist debate since the nineteenth century. What was nearly unique to the situation of the KPD, and what Wünderich presents very vividly in the study of local politics in Solingen that forms the centrepiece to his book, was the immediacy of the threat of counter-revolution. The problem was not simply that the Nazis were waiting in the wings after 1930, but also that the powers and freedoms of local self-government were already being eroded in the late 1920 , so that the retention or restoration of democracy at the local level had to be the first Teilforderung of any movement that hoped to head off a dangerous 
deterioration in the situation of the working class. In Solingen the most striking manifestation of this erosion was the refusal of the Social Democratic minister of the interior to ratify the election of a Communist mayor who had won the support of Solingen's Social Democratic as well as its Communist town councillors; this was only one of a series of refusals to ratify between $193^{\circ}$ and 1933 . The local KPD failed to mount a fight for his restoration, since it was less concerned with having a Communist in office, or even with gaining a tactical victory over the Weimar system, than with the fact that the actions of the Social Democrats in Berlin confirmed the opposition of interests betweer labour and the SPD postulated in the theory of 'social fascism'. Wünderich makes the point that the 'ultra-left' policy of the KPD represented an accurate prediction of the role that Social Democrats would play in the implementation of the Brüning government's deflationary policies, and that it was made credible by these and other actions of the Prussian Social Democrats, including police actions against demonstrators in Berlin and other cities. What the Solingen KPD failed to recognize, he argues, was that the local Social Democrats were further from controlling the system than they had ever been. During the mid-1920s Solingen was governed by a compromise between the bourgeois and socialist parties, presided over by a liberal mayor, characterized by extensive concessions to Communist organizations and activities in city life, and modified by a tradition of direct working-class action outside the parliamentary bodies. Between 1927 and 1929, however, the question of whether or not to co-operate with the SPD became an explicit issue among the bourgeois parties; the resulting split in the bourgeois block by 1929 found the right-wing parties in open opposition to the old consensus. As a result, the parties of the Weimar coalition, and especially the SPD, were left to fight a rearguard action against the attacks on local autonomy by regional and central government.

In short, developments that are familiar to students of national politics in the Weimar Republic were equally going forward at the local level. The difference was that in places like Solingen the Communists had a firm base from which to organize active opposition to such developments, in the form of institutionalized links between local government and a large popular movement. These, Wünderich implies, would have made possible the combination of parliamentary and extra-parliamentary action that the KPD so often preached, around such issues as the arbitrary exclusion of duly elected representatives from local government. And if the hopes of beating the central state through such actions were slim, they might have helped to broaden the base of popular resistance to 'fascization' and won new supporters for the KPD in the longer term. In Solingen, as in other German towns during the first depression winter (1929-30), demonstrations and the threat of public disorder compelled the town councillors to approve a Christmas bonus to the unemployed proposed by the KPD. This success was not built upon, but used by the Communists to legitimate the deliberately self-defeating tactic of proposing a Communist candidate for mayor whose rejection by the authorities they predicted in advance.

Wünderich is well aware of the important differences between the depression years and the 'classical' period of mass extra-parliamentary action in Germany, namely the early twenties. He even suggests at one point that such actions after 1929 were naturally limited in their effectiveness by the fact that they were carried out almost exclusively by the unemployed. In itself, this implies arguments about the political potential of the unemployed as such that should not be accepted a priori. But there is no question that the solidary action of politically and industrially organized 
workers had in the past proved a most effective basis for the extra-parliamentary exercise of power, and that the bases of that kind of solidarity had been worn down as the job market contracted. What is striking about the case of Solingen is that as late as 1928 the Communists did have access to that further source of working-class strength, through their dominant role in the local branches of the metalworkers' union (whose roots Stolle has already illuminated), and that they gambled their leadership away. In fact, as Wünderich describes them, developments in the trade union, resulting from the combination of the industriat climate and Communist political decisions, prefigured the pattern of conflict in local government. Adventurism on the part of the local Communist leadership provoked arbitrary punitive measures by the Social Democratic national executive, which the Communists chose not to fight within the framework of the union constitution.

If the actions of the unemployed and the tribunician role adopted by Communist parliamentarians on their behalf appear as a kind of compensation for the weakness of the KPD in the factories, then - in Solingen at least - that weak position was one the party had manoeuvred itself into. It is all the more remarkable therefore that the Communists proved equally resistant to recognizing that they had lost their hold on the workers in the factories and to acknowledging the value and potency of struggles carried on outside the factory, in the realms where direct political control of daily life could be contested. Wünderich is particularly good on the way this specific blindness operated in the KPD's approach to local government. He treats the crisis of local self-government in Germany as a crisis of ideology as well as of institutions. The modern forms of urban self-government in Germany were concessions wrung by the urban bourgeoisie from the absolutist state in the early nineteenth century. In the 1920 s the actual democratization of local government placed before sections of the bourgeoisie the prospect of losing control of institutions that they had created, and by the end of the decade it was clear that the price of maintaining control locally was abandonment not only of the principle of civic democracy, but even of local autonomy. That sections of the working class subscribed to the bourgeois ideology of 'self-government' of which these principles were a part was something only sporadically perceived by Communist theorists. Wünderich's introduction of the concept of ideology adds a particular depth to the survey of programmatic utterances that is practically obligatory for KPD historians. He proposes that the tension in the KPD's programme between the theoretical insistence that local government was an integral part of the capitalist state apparatus and the tactical willingness to use its institutions could only be resolved through recognizing and building on the motivating force of active popular belief in local self-government. As it was, discussion of the relevant issues - the extent to which workers were convinced that the local state was of a different nature from the national state, or to which they experienced its activities as less oppressive by virtue of their own rights to participate in controling it, or to which they simply felt a need to control the mechanisms that directed their lives - was exceptional in the KPD during the 1920s. At the beginning of the party's left-turn in I 929 there were signs within the Central Committee of an awareness of these problems and of the necessity for organizing struggles around the defence of democratic rights at the local level. But in early $193^{\circ}$ the Comintern declared open war on the 'democratic illusions of the masses', setting aside even the radical-democratic demands of labour movement tradition and putting in their place a comprehensive call for the creation of soviets as the organs of the coming revolution. This policy was never abandoned in principle before 1933, though it was occasionally contravened in practice. 
As in so many areas of KPD activity, the failure to take account of the force of ideology appears here as an internal weakness that could seriously limit the party's capacity to organize success. But the proposition that it is easier to rally people to an ideal of democracy than to the creation of radical alternatives is like the characterization of the unemployed as a weak or unreliable force for political change. Sometimes it is true and sometimes it isn't, and the extent to which it is true depends on the balance of physical force and economic power, cultural tradition, social distress and political expectation specific to the particular historical moment. For this reason, it is a pity that $W$ ünderich leaves his local study in I 930. The self-isolation of the KPD after that time means that its activities within local government in Solingen ceased to be of much consequence; but that leaves room for study of such actual success as the Communists might have had in the subsequent period, in efforts to organize around the issues of local government and the welfare state but outside of and in opposition to the official institutions. In the form on the one hand of various kinds of self-help for the unemployed, tenants and other members of local communities, and on the other of demands for workers' (pupils'/recipients') control of local agencies of the state, such efforts only came into their own in the KPD in I93I. It would have been a valuable contribution to Wünderich's argument had he gone on to demonstrate what remains an assumption in his work, that these embryonic manifestations of the soviet ideal had little or no resonance in the working-class community.

That in itself would still require explanation. Why should the appeal to an ideology of democratic self-government within legal bounds itself be more effective in building a political movement than the call to create alternatives? One circumstance affecting the willingness of members of the working class to gamble on the creation of unofficial alternatives to state agencies may be the extent to which such institutions already exist in some form. People who are practised in articulating opposition to the state and its laws and in providing their own alternatives, the representatives, that is, of what Stuart Macintyre calls an 'oppositional culture', are the natural addressees of the KPD's form of 'council Communism'. I have argued elsewhere that such impulses were present in some German working-class areas and that the 'street politics' of the KPD represents a tacit recognition of them. Wünderich leaves us to guess whether extra-legal self-help was practised by the Solingen working class to any significant degree, in the periods of relative social peace that came between large-scale popular actions. The implication of his work is that it wasn't, but his survey of the cultural background, as of the political foreground, is rather too thin to provide unequivocal support for this, one of many interesting points in his book. Although he acknowledges Erhard Lucas' advice and assistance, Arbeiterbewegung und Selbstverwaltung has little of the richness of texture and social detail that makes Lucas' Zwei Formen von Radikalismus a classic study of the bases of revolutionary politics at the local level in the earliest years of the Republic. ${ }^{10}$

For Stuart Macintyre, who looks at analogous issues in the British context, the question of the origin and consequences of an 'oppositional culture' is central, and his work suggests (although this is not an explicit concern of his) that under specific historical circumstances the combination of an 'oppositional culture' with an active ideology of democratic self-government can bear fruit for avowedly revolutionary movements. A practised expositor of Communist theory, Macintyre is not concerned

10 Erhard Lucas, Zwei Formen von Radikalismus in der deutschen Arbeiterbewegung (Frankfurt, I976). 
in Little Moscows with the logical content of explicit policies, though he points out in passing that the leaders of British Communism were as chary as their German comrades about granting local government and local reforms more than incidental importance in the class war. Nor does he show much interest in assessing long-term success and failure in his study of British Communism between the wars; neither the success of the CPGB nor its failures have had the epochal quality of the KPD's. He does seek to explain, however, how and why the Communists succeeded where they did, in briefly gaining a predominant influence in the politics of three working-class localities: the South Wales mining town of Mardy, the Scottish mining village Lumphinnans, and the textile-manufacturing communities in the Vale of Leven. His aim, as he states, is to illuminate the reasons for the CPGB's relative lack of appeal on the national scale and at the same time to examine the impact of unemployment on the British working class between the wars.

He also addresses directly, as none of the German works does, the issue of 'community politics'. This theme introduces a certain tension into the book, for Macintyre is clearly convinced of the priority of workplace relations in generating militancy. He has chosen his cases as examples of places where the worlds of work, kin, friendship and recreation interprenetrated to a high degree. Of the three, the Vale of Leven was the only area whose population was not overwhelmingly dominated, numerically and culturally, by the industrial working class, and even there the capitalists themselves, representatives of the industrialist or rentier class, were conspicuously absent after 1918. The working class was left to contest local power with the 'wee middle class', with the paradoxical result that class relations in the three areas had an 'incomplete, unbalanced' quality. Militancy, then, arose out of a system of social relations in which the classic forms of industrial confrontation with capital were relatively unimportant - the more so as the period under examination was one in which the active link between workplace and community was eroded by unemployment. Moreover, it was only in Mardy (among Macintyre's examples) that the experience of class relations at the workplace and the resulting militancy had been articulated in specifically political terms. While trade union militancy was a characteristic of both Mardy and Lumphinnans in the I920s, only the South Wales miners sided in their majority with the Communists in the dispute between the local Communist leadership and the union officials. Even there, the CP did not make significant electoral gains until after its power in the trade union lodge had been broken. The militancy of Lumphinnans' miners in the General Strike was succeeded by a series of trade union splits (with the Communists in a minority) and unofficial strikes, so that Macintyre can argue that social cohesiveness 'compensated' trade union division, while insisting that Communist influence was 'still rooted in the place of work'. In the Vale of Leven, the CP actually grew out of early unemployed and tenants' groups and after faltering in the mid-twenties reached its greatest strength in the depression; in a community where two-thirds of the workforce was unemployed in 1930 it is hardly surprising that Communist strength was based largely in associations outside the workplace. If the basis for collective consciousness in the mining towns was occupational identity (at points subverted, at others reinforced by unemployment), so Macintyre argues, then the social cement in the Vale of Leven was a sense of pride in local identity based in a 200-year tradition of associational life.

The cohesiveness based on various kinds of informal institutions acquired a new force when whole communities were hit by economic disaster. Unemployment was 
not the prerogative of industrial workers, and the poverty of the unemployed directly affected the situation of the 'wee middle classes' in trade and services, the problem being particularly acute in small towns. The Communists made various kinds of rhetorical appeals to people as members of a community. The claim of Vale of Leven Communists to be fighting for 'the bottom dog' echoes the German call to the 'labouring masses' and the oppressed of all classes. One of the most potent images for English as for German Communists was that of the Soviet Union, and the success of the 'Friends of the Soviet Union' in the Little Moscows, which Macintyre emphasizes, can be seen as a measure of the success of the CP in addressing concerns about the quality of life not strictly related to conditions of work. But the CPGB, like the KPD, went beyond rhetoric, to organizing struggles around such issues as schooling (the Lumphinnans Communists found widespread popular support for their campaign against corporal punishment), rents and evictions, and above all the administration of relief for the poor. These were carried on both within the institutions of local government and outside them. And when Macintyre comes to list the characteristics that set the Little Moscows apart from other, otherwise comparable communities, he names not only the preconditions for these struggles the relatively high degree of integration of the unemployed into the rest of the working-class community and the local labour movement and a generally high morale - but also their relative success in securing 'some limited advances' in relief. If Communists gained popular support by addressing concerns and interests specific to the sphere of reproduction, as it appears, in periods when those concerns stood in the foreground in the daily life of the working class, then they retained their constituency where and in so far as they succeeded in enforcing those interests. That they should succeed in some places and not in others was partly a result of differential leadership; Macintyre is not ashamed to state that the presence of determined and charismatic individuals in the local Communist movements contributed materially to their success. But the willingness of the workers of Mardy, Lumphinnans and the Vale to maintain an active challenge to the local authorities was a function of local tradition as well. In each place Macintyre identifies the elements of an 'oppositional culture' - in Mardy and the Vale a strict morality based on the chapel combined with longstanding distrust of the police, in Lumphinnans a practice of resolving local conflicts without recourse to formal institutions. Where it was allied to an explicitly political world-view, this culture could underpin the creation of alternative, unofficial institutions, as when a Fife Communist was appointed as bailie and proceeded to administer the law in terms of 'simple working-class morality as interpreted from the Communist viewpoint'.

This last phenomenon brings us back to the comparison with Wünderich's Solingen Communists, for it seems to offer a middle way between the polarities of 'council Communism' and 'democratic illusions'. The British experience suggests that sustaining an 'oppositional culture' did not necessarily mean abandoning an ideology of democrątic self-government; it could mean putting it into practice in radically subversive ways, through acts that guaranteed that the militancy generated by the experience of oppression and repression could take root and flourish in the hope of effecting change. And the value of such moments, where the revolutionary party exercises a kind of hegemony, in maintaining the morale of the working-class community by confirming its power, is not necessarily negated by the fact that they have usually been brief in Western industrial states.

The comparison between inter-war Britain and Germany suggests the importance 
of specific political traditions in the crystallization of such moments. Macintyre is at pains to show that the institutions of his 'oppositional cultures' were fundamentally democratic in spirit and structure, and in this they might be said to reflect the extent to which the ideal of popular participation has remained a compelling force in British politics, however differentially realized. The German experience was arguably rather different. If Wünderich argues in terms of a polarity between democracy and revolution, it is not simply because he is often employing the narrowly Marxist discourse of the KPD. The fact is that most historians with find it difficult to imagine a situation analogous to that of the Communist bailie arising in Germany between I 923 and I933; even in Solingen, a KPD stronghold, the Communists exercised influence on local politics through a compromise and with the sufferance of their bourgeois opponents, and the case of the Communist mayor in $193^{\circ}$ demonstrates how limited were the chances of even gaining the opportunity to use the system against itself. Although local government in the Weimar Republic was formally more democratic than in the British towns, to the extent that it was based on a universal franchise, it bore the marks of a long tradition of government and administration that was not only oligarchic but avowedly contemptuous of the civil rights of organized workers. The ambiguities peculiar to the local state in the Weimar Republic created the conditions in which a Communist movement prepared to mobilize resentments generated outside the workplace could flourish, though only so long as its supporters were willing to expose themselves to increasingly frustrating confrontations with the police.

Was there a way out of this dilemma for the KPD? If we want to consider the history of Communism in the light of the possibilities as well as the limits of 'community politics', then we need to take into account the structure as well as the spirit of the local state. In the light of the German case, it is worthwhile considering how the relative visibility of the influence exercised by central government or by local capitalist elites on local government affected the credibility of arguments about the 'capitalist system'. But it is equally important to examine the actual accessibility of local government and local agencies of the national state to influence and control by the population. The value of this kind of study is tacitly acknowledged by Macintyre, who deals in some detail with the niceties of unemployment relief and their effects on the pattern of local conflicts. He points out that the local government reform of $193^{\circ}$, by shifting responsibility for social policy from parish to district and county councils, broke the power of the Little Moscows, where the strength of the militants had been manifested in the resistance of parish councils to national policy - a cautionary tale for village Hampdens and Kirchturmleninisten. 